\title{
Diluted Sugar Mill Effluent Application with PGPR Improves the Performance of Maize (Zea mays L.) under an Arid Climate
}

\author{
Muhammad Ijaz, Muhammad Sarfraz, Ahmad Nawaz *, Tauqeer Ahmad Yasir, Ahmad Sher, \\ Abdul Sattar and Allah Wasaya \\ College of Agriculture, Bahauddin Zakariya University, Bahadur Sub-Campus, Layyah-3100, Pakistan; \\ muhammad.ijaz@bzu.edu.pk (M.I.); sarfrazagronomist@gmail.com (M.S.); tauqeer.yasir@gmail.com (T.A.Y.); \\ ahmad.sher@bzu.edu.pk (A.Sh.); abdulsattar04@gmail.com (A.Sa.); wasayauaf@gmail.com (A.W.) \\ * Correspondence: ahmadnawaz2006@gmail.com
}

Received: 2 March 2018; Accepted: 21 April 2018; Published: 4 May 2018

\begin{abstract}
The disposal of sugar mill effluent is a serious matter of concern for the sugar industry. In this regard, the dilution of sugar mill effluent in combination with plant growth promoting rhizobacteria (PGPR) might be a viable option for improving crop growth. In this study, we evaluated the potential of diluted sugar mill effluent (SME) and PGPR to improve maize (Zea mays L.) performance. Seeds of a maize hybrid (Pioneer 1543) were sown in $20 \mathrm{~kg}$ soil-filled pots. The pots were irrigated with various sugar mill effluent concentrations (viz. $0,15 \%, 30 \%, 45 \%, 60 \%$, $75 \%$ and $100 \% v / v$ ). The results indicated that application of SME up to a concentration of $75 \%$ improved the stay-green, leaf emergence, growth and productivity of maize. However, the application of SME at a concentration of $100 \%$ was detrimental for maize plants and decreased the maize growth. The application of PGPR was also beneficial for improvement in stay-green, leaf emergence, growth and productivity of maize as compared with control (no PGPR application). In conclusion, the use of SME at concentration of $75 \%$ in combination with PGPR was the most effective method for improvement in stay-green, leaf emergence, growth and productivity of maize.
\end{abstract}

Keywords: diluted sugar mill effluent; maize; stay-green; leaf emergence; PGPR; arid climate

\section{Introduction}

Maize (Zea mays L.) is an important cereal crop of Pakistan. It is consumed as food, fodder and feed by human beings, animals and poultry birds, respectively. In Pakistan, it is currently cultivated on 0.9 million hectares of land, to producing 1.3 million tonnes of product [1]. At present, the use of industrial effluents for irrigation is gaining momentum. In many areas of the world, treated and diluted industrial effluents have been used for irrigation purposes [2-4], owing to their positive influences on crop growth through the improvement in soil properties [5-7].

Among the various industrial effluents, effluents from the sugar industry are of great agricultural importance as they contain surplus quantities of zinc, manganese, iron, copper, magnesium, potassium, calcium, phosphorus and nitrogen [8]. Owing to the presence of these macro- and micronutrients, effluents from the sugar industry can be used as a substitute for chemical fertilizers [5], especially in the neighborhood areas of the sugar mills where the deposition of sugar effluents in suitable places always remains a serious matter of concern.

The farmers living in areas near the sugar mills utilize the effluents from sugar mills as an irrigation source, neglecting their impacts on crop and soil health [9]. However, the sugar industry effluents may contain some heavy metals, like copper and nickel, which may negatively affect crop performance 
when used for irrigation purpose [10]. This indicates that long-term use of effluents from sugar mills for irrigation purposes may deteriorate soil health and the quality of the produce. Therefore, it is vital that measures are adopted for judicious use of sugar mill effluents as an alternate source of irrigation, to allow sustainable crop production.

In this scenario, the use of sugar industry effluents after suitable dilution might be a useful option to reduce the harmful effects of sugar industry effluents on maize growth [3]. The other option is the use of plant growth-promoting rhizobacteria (PGPR) to improve the growth of plants irrigated with sugar mill effluents. The PGPRs consist of multiple groups of free-living soil bacteria that can boost the growth and development of plants in heavy metal-contaminated soils through various mechanisms [11-13].

For this study, we hypothesized that the use of sugar industry effluents after dilution in combination with PGPR might be a useful strategy for improving maize growth and grain yield.

\section{Materials and Methods}

\subsection{Site and Soil}

This study was carried out in pots (each containing $20 \mathrm{~kg}$ soil) in the greenhouse of College of Agriculture, Bahauddin Zakariya University, Bahadur Sub-Campus Layyah, Punjab, Pakistan. Before filling the pots with soil, the soil was sampled, air dried, crushed and sieved through a $2 \mathrm{~mm}$ sieve. These samples were analysed in regard to physico-chemical properties in the soil and in a water-testing laboratory. The experimental soil was sandy loam with a $\mathrm{pH}$ of 7.2 , total nitrogen content of $0.13 \mathrm{~g} \mathrm{~kg}^{-1}$, available phosphorous content of $7.6 \mathrm{ppm}$, electrical conductivity of $3.6 \mathrm{dS} \mathrm{m}^{-1}$, and extractable potassium content of $100 \mathrm{ppm}$. The lowest temperature recorded during the crop growth period was $11^{\circ} \mathrm{C}$ while the highest was $41.6^{\circ} \mathrm{C}$. The climate of Layyah is arid and had very low relative humidity during the experimental period.

\subsection{Collection of Sugar Mill Effluents and PGPRs}

The sugar mill effluent used in this study was collected once from the Layyah Sugar Mill, located in Layyah city, Pakistan. The effluent samples were collected in plastic containers from the point of disposal of the Layyah Sugar Mill. The sugar mill effluent had an electrical conductivity of $809 \mu \mathrm{S} \mathrm{cm}{ }^{-1}$, $\mathrm{pH}$ of 8.8, $\mathrm{Ca}+\mathrm{Mg}$ content of $7.88 \mathrm{ppm}$, sodium content of $0.21 \mathrm{ppm}$, bicarbonate content of $9.05 \mathrm{ppm}$, residual sodium carbonate content of $1.17 \mathrm{ppm}$, sodium adsorption ratio of 0.10 , potassium content of $150 \mathrm{ppm}$, nitrate content of $400 \mathrm{ppm}$, phosphate content of $150 \mathrm{ppm}$, cadmium content of $8.18 \mathrm{ppm}$ and copper content of $8.23 \mathrm{ppm}$, and zinc content of $15 \mathrm{ppm}$. The sugar mill effluent had no carbonate or chloride. The water chemical analysis was carried out as detailed elsewhere [14,15]. The bacterial strain, Bacillus sp. MWT-14 (accession no. KT933232), was used in this study for seed inoculation.

\subsection{Seed Source}

The certified seeds (uniform size, colour and weight) of maize hybrid (Pioneer 1543) were purchased from Pioneer seed company (private limited) Sahiwal.

\subsection{Experimental Design and Crop Husbandry}

The experiment was conducted in a completely randomized design with three replications (two pots per replicate). The experiment consisted of six various sugar mill effluent concentrations viz. $15 \%$, $30 \%, 45 \%, 60 \%, 75 \%, 100 \%$ and a control treatment irrigated with tap water. Each pot was irrigated with $800 \mathrm{~mL}$ of its respective concentration of test solution every three days. Crops were sown on 20 February 2016 in pots $(54 \mathrm{~cm} \times 36 \mathrm{~cm}$ ) after filling the pots with $20 \mathrm{~kg}$ of soil. The experiment was repeated over space to validate the results. Initially, five seeds were sown in each pot which were thinned to four plants per pot after uniform emergence. 


\subsection{Data Recording}

The plant samples were collected 13, 26 and 39 days after sowing to record data on the size of the leaf area per plant, number of leaves per plant, stem diameter, plant height, amount of dry biomass per plant and chlorophyll content index. One plant from each replicate was harvested on each sampling date to record the data on these parameters. One plant was left in each pot to record data on number of grains per cob, 100-grain weight and grain yield. The crops were harvested on 2 June 2016.

\subsection{Statistical Analysis}

Data collected on all parameters for both experiments was merged and was analyzed statistically using the Analysis of Variance Technique, and Fisher's Least Significantly Difference (LSD) test at a 1\% probability level was applied to compare the treatments' means [16].

\section{Results}

The application of sugar mill effluent significantly affected the size of the leaf area per plant, number of leaves per plant, stem diameter, plant height, chlorophyll content index, and amount of dry biomass per plant at 13, 26 and 40 days after sowing (DAS). Likewise, the application of PGPR also significantly affected the size of the leaf area per plant, number of leaves per plant, stem diameter, plant height, chlorophyll content index, and amount of dry biomass per plant at 13, 26 and 40 DAS, except for plant height at 13 DAS and stem diameter at 26 DAS. The interaction of sugar mill effluent with PGPR was also significant for plant height at 26 DAS, stem diameter at 26 DAS, the size of the leaf area at 26 and 40 DAS and amount of dry biomass per plant and chlorophyll content index at 13 , 26 and 40 DAS (Tables 1 and 2).

At 13 and 40 DAS, the highest plant height was recorded with the application of $75 \%$ sugar mill effluent which was statistically similar to the application of $60 \%$ sugar mill effluent at 13 DAS and the application of $30 \%$ and $45 \%$ sugar mill effluent at 40 DAS. At 26 DAS, the highest plant height was recorded with the application of $75 \%$ water effluent with PGPR which was statistically similar to the application of the same concentration of sugar mill effluent without PGPR, and to the application of $30 \%$ sugar effluent with PGPR (Table 1). At 13 and 26 DAS, the highest stem diameter was recorded with the application of $75 \%$ sugar mill effluent and that was statistically similar to the application of $60 \%$ and $15 \%$ sugar mill effluent. The highest stem diameter at 13 DAS was recorded with PGPR. At 40 DAS, the highest stem diameter was recorded with the application of $75 \%$ sugar mill effluent with/without PGPR which was statistically similar to the application of $30 \%$ sugar mill effluent with PGPR (Table 1). The highest number of leaves was recorded with the application of $75 \%$ sugar mill effluent at 13, 26 and 40 DAS which was statistically similar to the application of $60 \%$ sugar mill effluent at all sampling dates. The use of PGPR also improved the number of leaves per plant compared to the condition with no PGPR use, at 13, 26 and 40 DAS (Table 1).

At 13 DAS, the greatest leaf area was measured with the application of $75 \%$ sugar mill effluent. The use of PGPR also improved the size of the leaf area at 13 DAS. At 26 and 40 DAS, the greatest leaf area was recorded with the application of $75 \%$ sugar mill effluent with PGPR and that was statistically similar to the application of 30\% sugar mill effluent with PGPR at 26 DAS and to the application of $60 \%$ sugar mill effluent with PGPR at 40 DAS (Table 2). The highest amount of dry biomass per plant and the highest chlorophyll content index at 13, 26 and 40 DAS were recorded with the application of $75 \%$ sugar mill effluent with PGPR (Table 2).

The highest number of grains per cob, 100-grain weight and grain yield were recorded when the PGPRs were applied as opposed to no PGPRs application. Among the sugar mill effluents, the highest number of grains per cob, 100-grain weight and grain yield occurred with the application of $75 \%$ sugar mill effluent which was statistically similar to the application of $75 \%$ sugar mill effluent (Table 3). 
Table 1. Influence of diluted sugar mill effluent and PGPR on plant height, stem diameter and number of leaves per plant.

\begin{tabular}{|c|c|c|c|c|c|c|c|c|c|}
\hline & No PGPR & PGPR & Mean (SME) & No PGPR & PGPR & Mean (SME) & No PGPR & PGPR & Mean (SME) \\
\hline SME $(\%)$ & \multicolumn{2}{|c|}{13 days after sowing } & & \multicolumn{3}{|c|}{26 days after sowing } & \multicolumn{2}{|c|}{40 days after sowing } & \\
\hline & \multicolumn{9}{|c|}{ Plant height $(\mathrm{cm})$} \\
\hline 0 & 18.4 & 24.2 & $21.3^{c}$ & $37.0^{\mathrm{e}}$ & $45.3^{\mathrm{cd}}$ & $41.2^{\mathrm{d}}$ & 45.0 & 52.3 & $48.7^{c}$ \\
\hline 15 & 23.8 & 24.5 & $24.1^{\mathrm{abc}}$ & $52.2^{\mathrm{ab}}$ & $52.5^{\mathrm{ab}}$ & $52.3^{\mathrm{abc}}$ & 47.0 & 53.0 & $50.0^{c}$ \\
\hline 30 & 24.8 & 25.5 & $25.1^{\mathrm{abc}}$ & $50.3^{\mathrm{abc}}$ & $55.0^{\mathrm{a}}$ & $52.6^{\mathrm{ab}}$ & 59.0 & 59.3 & $59.2^{\mathrm{ab}}$ \\
\hline 45 & 23.7 & 23.8 & $23.7^{b c}$ & $47.5 \mathrm{bcd}$ & $50.5^{\mathrm{abc}}$ & $49.0^{b c}$ & 56.3 & 57.2 & $56.7^{\mathrm{ab}}$ \\
\hline 60 & 27.0 & 24.5 & $25.8^{\mathrm{ab}}$ & $49.5^{\mathrm{abcd}}$ & 47.7 bcd & $48.6^{c}$ & 54.2 & 56.3 & $55.3^{\mathrm{b}}$ \\
\hline 75 & 26.3 & 29.0 & $27.7^{\mathrm{a}}$ & $52.7^{a b}$ & $54.5^{\mathrm{a}}$ & $53.6^{\mathrm{a}}$ & 60.3 & 61.5 & $60.9^{\mathrm{a}}$ \\
\hline 100 & 21.3 & 22.0 & $21.7^{c}$ & $45.8^{\mathrm{cd}}$ & $43.5^{\mathrm{cd}}$ & $44.6^{\mathrm{d}}$ & 47.3 & 46.7 & $47.0^{\mathrm{c}}$ \\
\hline Mean (PGPR) & 23.6 & 24.8 & & $45.1^{\mathrm{b}}$ & $49.9^{\mathrm{a}}$ & & $52.7^{\mathrm{b}}$ & $55.2^{\mathrm{a}}$ & \\
\hline \multirow[t]{2}{*}{$\operatorname{LSD}(p \leq 0.05)$} & \multicolumn{3}{|c|}{$\mathrm{PGPR}=\mathrm{NS} ; \mathrm{SME}=3.9 ; \mathrm{PGPR} \times \mathrm{SME}=\mathrm{NS}$} & \multicolumn{3}{|c|}{$\mathrm{PGPR}=1.35 ; \mathrm{SME}=3.93 ; \mathrm{PGPR} \times$ SME: 6.41} & \multicolumn{3}{|c|}{$\mathrm{PGPR}=1.58 ; \mathrm{SME}=4.57 ; \mathrm{PGPR} \times \mathrm{SME}=\mathrm{NS}$} \\
\hline & \multicolumn{9}{|c|}{ Stem diameter $(\mathrm{cm})$} \\
\hline 0 & 4.2 & 3.6 & $3.9^{\mathrm{b}}$ & 5.4 & 6.3 & $5.9^{c}$ & $7.8^{\mathrm{d}}$ & $7.7^{\mathrm{d}}$ & $7.7^{\mathrm{c}}$ \\
\hline 15 & 4.5 & 5.4 & $4.9^{\mathrm{a}}$ & 8.2 & 7.9 & $7.5^{b}$ & $9.2^{\mathrm{bcd}}$ & $9.8^{\mathrm{bc}}$ & $9.5^{\mathrm{b}}$ \\
\hline 30 & 4.2 & 4.8 & $4.5^{\mathrm{b}}$ & 5.3 & 7.5 & $7.8^{b}$ & $7.5^{\mathrm{d}}$ & $11.0^{\mathrm{ab}}$ & $9.2^{b}$ \\
\hline 45 & 3.7 & 4.5 & $4.1^{\mathrm{ab}}$ & 7.4 & 7.6 & $7.5^{b}$ & $8.0^{\mathrm{cd}}$ & $8.8^{\mathrm{cd}}$ & $8.4^{\mathrm{bc}}$ \\
\hline 60 & 4.5 & 5.1 & $4.8^{\mathrm{a}}$ & 7.6 & 8.5 & $8.0^{\mathrm{b}}$ & $8.1^{\mathrm{cd}}$ & $9.3 \mathrm{bcd}$ & $8.7 \mathrm{bc}$ \\
\hline 75 & 4.7 & 5.2 & $5.0^{\mathrm{a}}$ & 9.8 & 10.1 & $9.9^{\mathrm{a}}$ & $12.8^{\mathrm{a}}$ & $12.2^{\mathrm{a}}$ & $12.5^{\mathrm{a}}$ \\
\hline 100 & 4.0 & 4.7 & $4.4^{\mathrm{ab}}$ & 7.6 & 7.1 & $7.3^{\mathrm{b}}$ & $8.9^{\mathrm{cd}}$ & $8.8^{\mathrm{cd}}$ & $8.9^{b c}$ \\
\hline Mean (PGPR) & $4.3^{\mathrm{b}}$ & $4.8^{\mathrm{a}}$ & & 7.5 & 7.9 & & $8.9^{\mathrm{b}}$ & $9.6^{\mathrm{a}}$ & \\
\hline $\operatorname{LSD}(p \leq 0.05)$ & \multicolumn{3}{|c|}{$\mathrm{PGPR}=0.24 ; \mathrm{SME}=0.69 ; \mathrm{PGPR} \times \mathrm{SME}=\mathrm{NS}$} & \multicolumn{3}{|c|}{$\mathrm{PGPR}=\mathrm{NS} ; \mathrm{SME}=1.21 ; \mathrm{PGPR} \times \mathrm{SME}=\mathrm{NS}$} & \multicolumn{3}{|c|}{$\mathrm{PGPR}=0.41 ; \mathrm{SME}=1.18 ; \mathrm{PGPR} \times \mathrm{SME}=1.93$} \\
\hline
\end{tabular}

$\mathrm{LSD}(p \leq 0.05) \quad \mathrm{PGPR}=0.24 ; \mathrm{SME}=0.69 ; \mathrm{PGPR} \times \mathrm{SME}=\mathrm{NS} \quad \mathrm{PGPR}=\mathrm{NS} ; \mathrm{SME}=1.21 ; \mathrm{PGPR} \times \mathrm{SME}=$
Number of leaves per plan

\begin{tabular}{|c|c|c|c|c|c|c|c|c|c|}
\hline \multicolumn{10}{|c|}{ 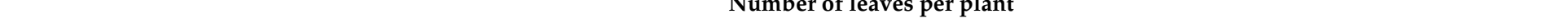 } \\
\hline 0 & 3.7 & 4.4 & $4.1^{\mathrm{bcd}}$ & 6.6 & 7.2 & $6.9^{\mathrm{cd}}$ & 6.6 & 7.6 & $7.1^{\mathrm{bcc}}$ \\
\hline 15 & 3.3 & 3.5 & $3.4^{\mathrm{d}}$ & 6.3 & 6.1 & $6.2^{\mathrm{d}}$ & 6.6 & 6.6 & $6.6^{\mathrm{d}}$ \\
\hline 30 & 4.0 & 4.3 & $4.1^{\mathrm{bcd}}$ & 6.7 & 7.5 & $7.1^{b c}$ & 7.5 & 7.7 & $7.6^{\mathrm{bcc}}$ \\
\hline 45 & 4.0 & 4.4 & $4.2^{\mathrm{abc}}$ & 6.5 & 7.7 & $7.1^{b c}$ & 8.0 & 9.3 & $8.7^{\mathrm{abc}}$ \\
\hline 60 & 4.5 & 5.1 & $4.8^{\mathrm{ab}}$ & 7.5 & 8.3 & $7.9^{\mathrm{ab}}$ & 8.1 & 9.5 & $8.8^{\mathrm{ab}}$ \\
\hline 75 & 5.0 & 5.1 & $5.0^{\mathrm{a}}$ & 7.7 & 9.0 & $8.3^{\mathrm{a}}$ & 9.7 & 11.2 & $10.4^{\mathrm{a}}$ \\
\hline 100 & 3.7 & 3.9 & $3.8^{\mathrm{cd}}$ & 6.3 & 7.2 & $6.8^{c}$ & 6.5 & 7.3 & $6.9^{\mathrm{cd}}$ \\
\hline n (PGPR) & $4.0^{\mathrm{b}}$ & $4.4^{\mathrm{a}}$ & & $6.8^{\mathrm{b}}$ & $7.6^{\mathrm{a}}$ & & $7.6^{\mathrm{b}}$ & $8.5^{\mathrm{a}}$ & \\
\hline
\end{tabular}

$\mathrm{LSD}(p \leq 0.05) \quad \mathrm{PGPR}=0.29 ; \mathrm{SME}=0.84 ; \mathrm{PGPR} \times \mathrm{SME}=\mathrm{NS} \quad \mathrm{PGPR}=0.30 ; \mathrm{SME}=0.86 ; \mathrm{PGPR} \times \mathrm{SME}=\mathrm{NS} \quad \mathrm{PGPR}=0.29 ; \mathrm{SME}=0.84 ; \mathrm{PGPR} \times \mathrm{SME}=\mathrm{NS}$

Means of main effects and interactions sharing the same case letter for a parameter at each sampling date do not differ significantly at $p \leq 0.05$; SME $=$ diluted sugar mill effluent; $\mathrm{PGPR}=$ plant growth promoting rhizobacteria; $\mathrm{NS}=$ non-significant. LSD, least significant difference. 
Table 2. Influence of diluted sugar mill effluent and PGPR on size of leaf area, amount of dry biomass per plant and chlorophyll content of maize.

\begin{tabular}{|c|c|c|c|c|c|c|c|c|c|}
\hline & No PGPR & PGPR & Mean (SME) & No PGPR & PGPR & Mean (SME) & No PGPR & PGPR & Mean (SME) \\
\hline SME $(\%)$ & \multicolumn{3}{|c|}{13 days after sowing } & \multicolumn{3}{|c|}{26 days after sowing } & \multicolumn{3}{|c|}{40 days after sowing } \\
\hline & \multicolumn{9}{|c|}{ Leaf area $\left(\mathrm{cm}^{2}\right)$} \\
\hline 0 & 40.7 & 51.3 & $46.0 \mathrm{bc}$ & $90.7^{\mathrm{i}}$ & $127.3^{\mathrm{h}}$ & $109.0^{\mathrm{e}}$ & $325.2^{\mathrm{f}}$ & $379.5^{\mathrm{e}}$ & $352.3^{\mathrm{e}}$ \\
\hline 15 & 49.7 & 53.0 & $51.3^{\mathrm{b}}$ & $152.4 \mathrm{gh}$ & $234.6^{\mathrm{bc}}$ & $193.5^{c}$ & $391.3^{\mathrm{e}}$ & $454.8^{\mathrm{d}}$ & $423.0^{\mathrm{d}}$ \\
\hline 30 & 44.7 & 50.3 & $47.5^{\mathrm{bc}}$ & $184.3^{\text {ef }}$ & $252.7^{\mathrm{ab}}$ & $1218.5^{b}$ & $343.7^{\text {ef }}$ & $455.4^{\mathrm{d}}$ & $399.5^{d}$ \\
\hline 45 & 48.3 & 51.7 & $50.0^{\mathrm{b}}$ & $157.2^{\mathrm{fg}}$ & 199.3 de & $178.3^{\mathrm{cd}}$ & $453.8^{\mathrm{d}}$ & $560.0^{\mathrm{c}}$ & $506.9^{\mathrm{c}}$ \\
\hline 60 & 50.7 & 54.7 & $52.7^{\mathrm{b}}$ & $219.0^{\mathrm{cd}}$ & $234.3^{b c}$ & $226.7^{\mathrm{ab}}$ & $540.0^{\mathrm{c}}$ & $633.1^{a b}$ & $586.5^{\mathrm{b}}$ \\
\hline 75 & 54.0 & 65.3 & $59.7^{\mathrm{a}}$ & $211.0^{\text {cde }}$ & $275.7^{\mathrm{a}}$ & $243.3^{\mathrm{a}}$ & $584.1^{b c}$ & $682.8^{\mathrm{a}}$ & $633.5^{\mathrm{a}}$ \\
\hline 100 & 39.7 & 42.7 & $41.2^{c}$ & $155.2^{\mathrm{g}}$ & $189.0^{\mathrm{e}}$ & $172.1^{\mathrm{d}}$ & $386.0^{\mathrm{e}}$ & $453.8^{\mathrm{d}}$ & $419.9^{\mathrm{d}}$ \\
\hline Mean (PGPR) & $46.8^{\mathrm{b}}$ & $52.7^{\mathrm{a}}$ & & $167.1^{\mathrm{b}}$ & $216.1^{\mathrm{a}}$ & & $432.0^{\mathrm{b}}$ & $517.1^{\mathrm{a}}$ & \\
\hline $\operatorname{LSD}(p \leq 0.05)$ & \multicolumn{3}{|c|}{$\mathrm{PGPR}=2.3 ; \mathrm{SME}=6.8 ; \mathrm{PGPR} \times \mathrm{SME}=\mathrm{NS}$} & \multicolumn{3}{|c|}{$\mathrm{PGPR}=5.8 ; \mathrm{SME}=16.9 ; \mathrm{PGPR} \times \mathrm{SME}=27.6$} & \multicolumn{3}{|c|}{$\mathrm{PGPR}=10.6 ; \mathrm{SME}=30.8 ; \mathrm{PGPR} \times \mathrm{SME}=50.3$} \\
\hline & \multicolumn{9}{|c|}{ Amount of dry biomass per plant (g) } \\
\hline 0 & $0.5 \mathrm{~g}$ & $2.3^{\text {bcde }}$ & $1.4^{\mathrm{e}}$ & $1.9^{\mathrm{e}}$ & $1.4^{\mathrm{f}}$ & $1.7^{\mathrm{e}}$ & $2.9^{\mathrm{hi}}$ & $3.3 \mathrm{gh}$ & $3.1^{\mathrm{e}}$ \\
\hline 15 & $2.1^{\mathrm{de}}$ & $2.3^{\text {bcde }}$ & $2.2^{b c}$ & $1.8^{\text {ef }}$ & $1.7^{\text {ef }}$ & $1.8^{\mathrm{e}}$ & $5.2^{d}$ & $5.2^{\mathrm{d}}$ & $5.2^{\mathrm{c}}$ \\
\hline 30 & $2.4^{\mathrm{bcd}}$ & 2.3 bcde & $2.4 \mathrm{bc}$ & $2.6^{\mathrm{cd}}$ & $2.5^{\mathrm{cd}}$ & $2.6^{\mathrm{c}}$ & $5.2^{\mathrm{d}}$ & $4.4^{\text {ef }}$ & $4.8^{\mathrm{d}}$ \\
\hline 45 & $2.3^{\text {cde }}$ & $2.6^{\mathrm{b}}$ & $2.4^{b}$ & $2.3^{\text {de }}$ & $2.6^{\mathrm{cd}}$ & $2.4^{\mathrm{cd}}$ & $5.2^{d}$ & $5.0^{\mathrm{de}}$ & $5.1^{\mathrm{cd}}$ \\
\hline 60 & $2.1^{\mathrm{e}}$ & $2.3^{\text {bcde }}$ & $2.2^{\mathrm{c}}$ & $2.9^{\mathrm{c}}$ & $3.6^{\mathrm{b}}$ & $3.3^{b}$ & $6.2^{b}$ & $5.4^{\mathrm{d}}$ & $5.8^{\mathrm{b}}$ \\
\hline 75 & $2.5^{b c}$ & $3.6^{\mathrm{a}}$ & $3.1^{\mathrm{a}}$ & $3.7^{\mathrm{b}}$ & $5.5^{\mathrm{a}}$ & $4.6^{\mathrm{a}}$ & $6.0^{\mathrm{bc}}$ & $7.3^{\mathrm{a}}$ & $6.7^{\mathrm{a}}$ \\
\hline 100 & $1.5^{\mathrm{f}}$ & $1.7^{\mathrm{f}}$ & $1.6^{\mathrm{d}}$ & $1.8^{\text {ef }}$ & $2.5^{\mathrm{cd}}$ & $2.1^{\mathrm{e}}$ & $2.5^{\mathrm{i}}$ & $3.8^{\mathrm{fg}}$ & $3.2^{\mathrm{e}}$ \\
\hline Mean (PGPR) & $1.9^{\mathrm{b}}$ & $2.5^{\mathrm{a}}$ & & $2.4^{\mathrm{b}}$ & $2.8^{\mathrm{a}}$ & & $4.7^{\mathrm{b}}$ & $4.9^{\mathrm{a}}$ & \\
\hline $\operatorname{LSD}(p \leq 0.05)$ & \multicolumn{3}{|c|}{$\mathrm{PGPR}=0.07 ; \mathrm{SME}=0.20 ; \mathrm{PGPR} \times \mathrm{SME}=0.32$} & \multicolumn{3}{|c|}{$\mathrm{PGPR}=0.11 ; \mathrm{SME}=0.32 ; \mathrm{PGPR} \times \mathrm{SME}=0.53$} & \multicolumn{3}{|c|}{$\mathrm{PGPR}=0.14 ; \mathrm{SME}=0.41 ; \mathrm{PGPR} \times \mathrm{SME}=0.66$} \\
\hline & \multicolumn{9}{|c|}{ Chlorophyll content index (Spade value) } \\
\hline 0 & $9.0^{\mathrm{de}}$ & $11.5^{b c}$ & $10.3^{b}$ & $7.3^{\text {bcde }}$ & $6.3^{\mathrm{e}}$ & $6.8^{c}$ & 7.9 cde & $6.1^{\mathrm{f}}$ & $7.0^{\mathrm{e}}$ \\
\hline 15 & $11.6^{\mathrm{bc}}$ & $11.9^{\mathrm{bc}}$ & $11.7^{\mathrm{a}}$ & $7.0^{\text {cde }}$ & $7.9^{\mathrm{bcd}}$ & $7.4^{\mathrm{bc}}$ & $8.0^{\mathrm{cd}}$ & $9.2^{b c}$ & $8.6^{\mathrm{bc}}$ \\
\hline 30 & $10.8^{\mathrm{cd}}$ & $13.3^{\mathrm{ab}}$ & $11.8^{\mathrm{a}}$ & $7.6^{\text {bcde }}$ & $7.8^{\text {bcde }}$ & $7.7^{b c}$ & $7.0^{\mathrm{def}}$ & $8.3^{\mathrm{cd}}$ & $7.7^{\mathrm{cd}}$ \\
\hline 45 & 9.2 de & $11.5 \mathrm{bc}$ & $10.3^{\mathrm{b}}$ & $8.6^{\mathrm{b}}$ & $6.6^{\mathrm{de}}$ & $7.6^{\mathrm{bc}}$ & $8.9 \mathrm{bc}$ & $6.2^{\mathrm{ef}}$ & $7.5^{\mathrm{d}}$ \\
\hline 60 & $7.2^{\text {ef }}$ & $11.3 \mathrm{bc}$ & $9.3^{b}$ & $7.5^{\text {bcde }}$ & $8.2^{b c}$ & $7.9^{b}$ & $7.9^{\mathrm{cd}}$ & $10.0^{\mathrm{b}}$ & $9.0^{\mathrm{b}}$ \\
\hline 75 & $10.4^{\mathrm{cd}}$ & $14.1^{\mathrm{a}}$ & $12.3^{\mathrm{a}}$ & $8.8^{\mathrm{b}}$ & $11.2^{\mathrm{a}}$ & $10.0^{\mathrm{a}}$ & $9.2^{b c}$ & $12.6^{\mathrm{a}}$ & $10.9^{\mathrm{a}}$ \\
\hline 100 & $5.9^{\mathrm{f}}$ & $9.8^{\mathrm{cd}}$ & $7.9^{\mathrm{c}}$ & $7.0^{\text {cde }}$ & $8.3^{\mathrm{bc}}$ & $7.6^{\mathrm{bc}}$ & $5.8^{\text {cde }}$ & $7.8^{\text {cde }}$ & $6.8^{\mathrm{d}}$ \\
\hline Mean (PGPR) & $9.1^{\mathrm{b}}$ & $11.9^{\mathrm{a}}$ & & $7.48^{\mathrm{b}}$ & $8.0^{\mathrm{a}}$ & & $7.8^{\mathrm{b}}$ & $8.6^{\mathrm{a}}$ & \\
\hline $\operatorname{LSD}(p \leq 0.05)$ & \multicolumn{3}{|c|}{$\mathrm{PGPR}=0.45 ; \mathrm{SME}=1.29 ; \mathrm{PGPR} \times \mathrm{SME}=2.11$} & \multicolumn{3}{|c|}{$\mathrm{PGPR}=0.32 ; \mathrm{SME}=0.93 ; \mathrm{PGPR} \times \mathrm{SME}=1.51$} & \multicolumn{3}{|c|}{$\mathrm{PGPR}=0.35 ; \mathrm{SME}=1.02 ; \mathrm{PGPR} \times \mathrm{SME}=1.66$} \\
\hline
\end{tabular}

Means of main effects and interactions sharing the same case letter for a parameter at each sampling date do not differ significantly at $p \leq 0.05$; SME $=$ diluted sugar mill effluent; PGPR = plant growth promoting rhizobacteria; NS = non-significant. 
Table 3. Influence of diluted sugar mill effluent and PGPR on number of grains per cob, 100-grain weight and grain yield of maize.

\begin{tabular}{cccc}
\hline Treatments & Grains per Cob & 100-Grain Weight (g) & Grain Yield (g/plant) \\
\hline Plant growth promoting rhizobacteria & $270^{\mathrm{a}}$ & $26.1^{\mathrm{a}}$ & $53.0^{\mathrm{a}}$ \\
PGPRs & $244^{\mathrm{b}}$ & $19.6^{\mathrm{b}}$ & $36.4^{\mathrm{b}}$ \\
No PGPRs & 23 & $3.1^{\mathrm{a}}$ & $6.6^{\mathrm{a}}$ \\
LSD $(p \leq 0.05)$ & & & $36.0^{\mathrm{d}}$ \\
Sugar mill effluent & $199^{\mathrm{d}}$ & $18.1^{\mathrm{c}}$ & $41.3^{\mathrm{b}}$ \\
0 & $231^{\mathrm{c}}$ & $22.8^{\mathrm{b}}$ & $43.7^{\mathrm{b}}$ \\
15 & $248^{\mathrm{b}}$ & $23.1^{\mathrm{b}}$ & $45.4^{\mathrm{b}}$ \\
30 & $258^{\mathrm{b}}$ & $23.3^{\mathrm{a}}$ & $51.4^{\mathrm{a}}$ \\
45 & $308^{\mathrm{a}}$ & $24.9^{\mathrm{a}}$ & $53.1^{\mathrm{a}}$ \\
60 & $333^{\mathrm{a}}$ & $25.5^{\mathrm{a}}$ & $41.9^{\mathrm{b}}$ \\
75 & $222^{\mathrm{c}}$ & $22.1^{\mathrm{b}}$ & $5.0^{\mathrm{b}}$ \\
\hline
\end{tabular}

Means of main effects and interactions sharing the same case letter for a parameter do not differ significantly at $p \leq 0.05$.

\section{Discussion}

This study indicated that the use of diluted sugar mill effluent in maize plants can improve the size of the leaf area per plant, the number of leaves per plant, the stem diameter, the plant height, the chlorophyll content index, and the amount of dry biomass per plant. Indeed, the sugar mill effluents consist of surplus quantities of macronutrients (magnesium, potassium, calcium, phosphorus, nitrogen) and micronutrients (zinc, iron, manganese) $[3,8,17]$, which might have resulted in the improvement in growth of maize when used after dilution. The role of macronutrients and micronutrients present in sugar mill effluent in improving the growth of cereals including maize has been reported widely [3,17]. The improvement in the chlorophyll content in this study due to the application of diluted sugar mill effluent might be attributed to the presence of magnesium, manganese, and iron [18] within the sugar mill effluent which are key elements for the synthesis of chlorophyll in crop plants.

The higher concentrations of sugar mill effluent without dilution negatively impacted the growth of maize. This might be due to the presence of a surplus amount of heavy metals (cadmium and chromium) present in the effluent which inhibit seed germination and growth by interfering with metabolic activities $[3,19,20]$, and altering the seed-water interaction which is necessary to trigger enzyme activity [21]. Various studies have reported that long-term application of sugar mill and other industry effluents may enhance the buildup of heavy metals in the soil to a toxic level $[3,10,22]$, thus contaminating the soil and eventually, the growth of crop plants [3].

In this study, the use of PGPR was beneficial for improving the growth of maize irrigated with various concentrations of sugar mill effluent. This indicates that the use of PGPR coupled with the use of sugar mill effluent might be helpful for improving plant growth through conquering the heavy metal toxicity due to the sole use of sugar mill effluent [12,23]. PGPRs colonize around the roots of plants and prevent heavy metal toxicity through the production and secretion of various regulatory compounds (viz. siderophores, phytohormones and heavy metal binding proteins) [24]. PGPR also produce phytohormones (e.g., indole acetic acid) which improves plant growth and retards metal uptake in plants [25]. This study also indicated that the dilution of sugar mill effluents was most useful for growth promotion as indicated in earlier studies $[3,26]$. Some other studies have also reported that PGPRs are very useful for crop growth promotion in contaminated soils [27-29].

The highest grain yield was recorded when the PGPRs were applied alongside the application of $75 \%$ and $60 \%$ sugar mill effluents (Table 3 ). The high grain yield with these treatments was the outcome of better leaf emergence, growth and improved stay-green which ultimately enhanced the number of grains per cob and the 100-grain weight, thus resulting in higher grain yields [6]. Indeed, grain weight 
is an important yield-contributing trait which is related to stay-green in cereals [30] under different abiotic stresses.

\section{Conclusions}

The use of SME at a concentration of 75\% in combination with PGPRs was most effective for improving in the stay-green, leaf emergence, growth and productivity of maize under an arid climate.

Author Contributions: M.I. and T.A.Y. conceived and designed the experiments; M.S. performed the experiments; A.Sh. and A.Sa. analyzed the data; A.W. contributed reagents/materials/analysis tools; A.N. wrote the paper.

Acknowledgments: The authors are grateful to Bahauddin Zakariya University Multan for providing the funds for carrying this experiment. However, the university has provided no funds for covering the costs to publish in open access.

Conflicts of Interest: The authors declare no conflict of interest.

\section{Nomenclature}

$\begin{array}{ll}\text { PGPR } & \text { plant growth promoting rhizobacteria } \\ \text { SME } & \text { sugar mill effluent } \\ \text { DAS } & \text { days after sowing } \\ \text { LSD } & \text { least significant difference } \\ \mathrm{Kg} & \text { kilogram } \\ \mathrm{g} & \text { gram } \\ \% & \text { percentage }\end{array}$

\section{References}

1. Government of Pakistan. Pakistan Economic Survey 2015-2016; Ministry of Finance: Islamabad, Pakistan, 2016.

2. Adekola, F.A.; Salami, N.; Lawai, S.O. Some trace elements determination in surface water and sediments of Oyunriver, Kwara State, Nigeria. Niger. J. Pure Appl. Sci. 2003, 18, 1418-1422.

3. Kumar, V. Sugar mill effluent utilization in the cultivation of maize (Zea mays L.) in two seasons. J. Waste Manag. 2014, 2014, 408509. [CrossRef]

4. Maucieri, C.; Cavallaro, V.; Caruso, C.; Borin, M.; Milani, M.; Barbera, A.C. Sorghum biomass production for energy purpose using treated urban wastewater and different fertilization in a Mediterranean environment. Agriculture 2016, 6, 67. [CrossRef]

5. Arafat, S.M. Evaluation of sugar cane filter mud cake on improving soil characteristics and water melon yield. Egypt. J. Appl. Sci. 1994, 9, 287-295.

6. Al-Isawi, R.H.K.; Scholz, M.; Al-Faraj, F.A.M. Assessment of diesel-contaminated domestic wastewater treated by constructed wetlands for irrigation of chillies grown in a greenhouse. Environ. Sci. Pollut. Res. 2016, 23, 25003-25023. [CrossRef] [PubMed]

7. Barbera, A.C.; Maucieri, C.; Cavallaro, V.; Ioppolo, A.; Spagna, G. Effects of spreading olive mill wastewater on soil properties and crops, a review. Agric. Water Manag. 2013, 119, 43-53. [CrossRef]

8. Ezhilvannan, D.; Sharavanan, P.S.; Vijayaragavan, M. Effect of sugar mill effluent on changes of growth and amino acid and protein contents of maize (Zea mays L.) plants. J. Ecobiotechnol. 2011, 3, 26-29.

9. Kisku, G.C.; Barman, S.C.; Bhargava, S.K. Contamination of soil and plants potentially toxic elements irrigated with mixed industrial effluent and impact in the environment. Water Air Soil Pollut. 2000, 120, 121-137. [CrossRef]

10. Kumar, V.; Chopra, A.K. Pearl millet (Pennisetum Glaucum L.) response after ferti-Irrigation with sugar mill effluent in two seasons. Int. J. Recycl. Org. Waste Agric. 2014, 3, 6. [CrossRef]

11. Belimov, A.A.; Kunakova, A.M.; Safronova, V.I.; Stepanok, V.V.; Yudkin, L.Y.; Alekseev, Y.V.; Kozhemyakov, A.P. Employment of rhizobacteria for the inoculation of barley plants cultivated in soil contaminated with lead and cadmium. Microbiology 2004, 73, 99-106.

12. Hansda, A.; Kumar, V.; Anshumali, A.; Usmani, Z. Phytoremediation of heavy metals contaminated soil using plant growth promoting rhizobacteria (PGPR): A current perspective. Recent Res. Sci. Technol. 2014, 6, 131-134. 
13. Upadhyay, N.; Vishwakarma, K.; Singh, J.; Mishra, M.; Kumar, V.; Rani, R.; Mishra, R.K.; Chauhan, D.K.; Tripathi, D.K.; Sharma, S. Tolerance and reduction of chromium (VI) by Bacillus sp. MNU16 isolated from contaminated coal mining soil. Front. Plant Sci. 2017, 8, 778. [CrossRef] [PubMed]

14. Clesceri, L.S.; American Public Health Association. Methods for the Examination of Water and Wastewater, 2nd ed.; American Public Health Association: Washington, DC, USA, 2005.

15. Chaturvedi, R.K.; Sankar, K. Laboratory Manual for the Physico-Chemical Analysis of Soil, Water and Plant; Wildlife Institute of India: Dehradun, India, 2006.

16. Steel, R.G.D.; Torrie, J.H.; Dickey, D.A. Principles and Procedures of Statistics: A Biometric Approach, 3rd ed.; McGraw Hill Book Co. Inc.: New York, NY, USA, 1996.

17. Kumar, V.; Chopra, A.K. Fertigational effects of sugar mill effluent on agronomical characteristics of high yield cultivar of sugarcane (Saccharum officinarum L.) in two seasons. Acta Adv. Agric. Sci. 2014, 2, 17-39.

18. Vijayaragavan, M.; Prabhahar, C.; Sureshkumar, J.; Natarajan, A.; Vijayarengan, P.; Sharavanan, S. Soil irrigation effect of sugar mill effluent on changes of growth and biochemical contents of Raphanus sativus $\mathrm{L}$. Curr. Bot. 2011, 2, 9-13.

19. Kaushik, A.; Kadyan, B.P.; Kaushik, C.P. Sugar mill effluent effects on growth, photosynthetic pigments and nutrient uptake in wheat seedlings in aqueous vs. soil medium. Water Air Soil Pollut. 2004, 87, $39-46$. [CrossRef]

20. Srivastava, S.; Chopra, A.K.; Sharma, P.; Kumar, V. Amendment of sugar mill wastewater irrigation on soil biohydrological properties and yield of Vigna umguiculata L. Walp in two seasons. Commun. Soil Sci. Plant Anal. 2017, 48, 511-523. [CrossRef]

21. Azza Mazher, A.M.; Fatma, E.L.; Quensi, E.M.; Farahat, M.M. Responses of ornamental plants and woody trees to salinity. World J. Agric. Sci. 2007, 3, 386-395.

22. Singandhupe, R.B.; Bankar, M.C.; Anand, P.S.B.; Patil, N.G. Management of drip irrigated sugarcane in western India. Arch. Agron. Soil Sci. 2008, 54, 629-649. [CrossRef]

23. Rajesh, M.; Natarajan, K.; Renish, N. Strategies of reducing the toxicity of sugar mill effluent by using biofertilizer inoculants. Int. Lett. Nat. Sci. 2015, 5, 11-17. [CrossRef]

24. Shinwari, K.I.; Shah, A.U.; Afridi, M.I.; Zeeshan, M.; Hussain, H.; Hussain, J.; Ahmad, O. Application of plant growth promoting rhizobacteria in bioremediation of heavy metal polluted soil. Asian J. Multidiscip. Stud. 2015, 3, 179-185.

25. Zaidi, S.; Usmani, S.; Singh, B.R.; Musarrat, J. Significance of Bacillus subtilis strain SJ 101 as a bioinoculant for concurrent plant growth promotion and nickel accumulation in Brassica juncea. Chemosphere 2006, 64, 991-997. [CrossRef] [PubMed]

26. Parmila, R.; Sanjeev, K. Soil irrigation effect of sugarcane industrial effluent on changes of level of chlorophyll, growth and yield of Triticum aestivum cv. PBW-226. Int. J. Plant Sci. 2010, 5, 170-173.

27. Xun, F.; Xie, B.; Liu, S.; Guo, C. Effect of plant growth-promoting bacteria (PGPR) and arbuscular mycorrhizal fungi (AMF) inoculation on oats in saline-alkali soil contaminated by petroleum to enhance phytoremediation. Environ. Sci. Pollut. Res. 2015, 22, 598-608. [CrossRef] [PubMed]

28. Vivas, A.; Biro, B.; Ruiz-Lozano, J.M.; Barea, J.M.; Azcon, R. Two bacterial strains isolated from a Zn-polluted soil enhance plant growth and mycorrhizal efficiency under Zn-toxicity. Chemosphere 2006, 62, 1523-1533. [CrossRef] [PubMed]

29. Di Gregorio, S.; Barbafieri, M.; Lampis, S.; Sanangelantoni, A.M.; Tassi, E.; Vallini, G. Combined application of Triton X-100 and Sinorhizobium sp. Pb002 inoculum for the improvement of lead phytoextraction by Brassica juncea in EDTA amended soil. Chemosphere 2006, 63, 293-299. [CrossRef] [PubMed]

30. Nawaz, A.; Farooq, M.; Cheema, S.A.; Yasmeen, A.; Wahid, A. Stay green character at grain filling ensures resistance against terminal drought in wheat. Int. J. Agric. Biol. 2013, 15, 1272-1276.

(C) 2018 by the authors. Licensee MDPI, Basel, Switzerland. This article is an open access article distributed under the terms and conditions of the Creative Commons Attribution (CC BY) license (http://creativecommons.org/licenses/by/4.0/). 